\title{
CHANGING OCCUPATIONAL PATTERN AMONG THE BISH- OWKARMAS: A CASE STUDY OF HEMJA VDC
}

\section{Deb Bahadur CHETRY}

\section{ABSTRACT}

This paper deals on the current issues of changing patterns of traditional occupational skills and technologies and management of the traditional skills and technologies of Bishowkarmas of Hemja VDC from an anthropological perspective. This paper highlights the salient traditional occupational features and recommendations of policies for the promotion of traditional occupation for self reliant. It also deals with the causes of intergenerational occupational mobility and shift from the traditional occupation of Bishowkarmas. The findings are based on a field level investigation, observation and focused group discussion among the Bishowkarmas and analysis from multidisciplinary and participatory approach. Major causes for the occupational mobility issues among the surveyed population include socio-cultural practices, modernization, industrialization, urbanization and widespread use of western education system. The main management and promotional issues includes reservation, strong law against touchable practices, arrangement of raw materials and market. Promotional strategy comprise of socio-cultural and improved institutional capability aspects which emphases on issues like giving importance to native products and traditional occupational skills and technologies and create space for native products for conserving traditional art and promoting for the self reliant.

KEYWORDS: Traditional occupation, Patron-client, Hill Dalits, Occupational Preference, Occupational Mobility.

\section{INTRODUCTION}

Humanity have come into new millennium, even while there are new forms of exploitation, torture, war and caste racial and class divisions are developing and continuing in contemporary India and Nepal. There are thousands of people suffering within the Verna system created by the Hindu religious practices. Those categorized at the bottom of this Hindu social organization system have been designated as "Untouch- 
able", or 'Dalits'. Despite thirty years having passed since the Amendment of the International Convention on the Elimination of all forms of Racial Discrimination (ICERD), Half a century has been passed since, a declaration of the 'Universal Human Rights' the Dalits in this subcontinent has not achieved social justice. Nepali law has declared caste discrimination a crime, but those who would implement those laws they themselves. Practice the untouchability. Additionally, a deeply rooted ingrained sense of inferiority within Dalits has been difficult to eradicate among themselves, Dalits practice untouchability, argue and fracture their own unity (Kisan ; 2005).

Nepal is a country, which exhibits ethnic and cultural mosaic and cultural plurality. Nepali society possesses the various religious, cultural, ethnic and linguistic constituents, which has sought shelter here at various periods of the history. Caste system is the basic foundation of the Hindu society. Caste system is based on the Varna system. Nepalese social structure is based on the varna system, where different caste groups and individuals interact and are interdependent upon each other. The caste or Varna system is based on five primary social classifications. These are, the Brahman (Priest), the Kshatriyas (Warrior or administrator), the Vaysha (Trader), the Sudra (Labour) and the untouchable or polluted.

Especially Sudras are specified for the high born societies. My study has focused on the Bishowkarmas, a specific group among Dalits (Sudras). Traditionally Dalits used patron-client relationship, where they received Jajmani and Bali from the high born society. But now the Bali system is losing its roots in the society. The Bishowkarmas had totally left doing Bali system. Since few years not only works in Bali system they left but also their occupation (B.K; 2007). Bishowkarmas, a major Dalits group, have further sub- branched as Kami, Sunar, Tamata, Chunara and Kadra, who have traditionally adopted the occupation as Iron work, gold work, copper work, wooden work, and animal husbandry respectively (Pandey,2006). Not only that every occupation has a caste identity, but also that each caste has an occupation or group of related occupations. The caste structure is fundamentally a labour structure, a system of interrelated services originating in spe- 
cialized groups as traditionalized in a religious matrix. Due to this history they are always been exploited by high born societies.

\section{THE PROBLEM AND OBJECTIVES}

Dalit people who cover around 15 to 20 percentage of the total population of the country were and are suffering from the caste based discrimination. They were ranked in a lower grade of vertical social hierarchy. Still several Dalits have to serve the higher caste people to meet the livelihood sufficiency. Dalits have been marginalized from various social and economical opportunities. According to Human Developing Report (2000), 90 percentage Dalits were below the poverty line. The traditional occupation of the Dalits people were threatened and could not continue further because of industrial production and open market (Sharma; 2001).

This study has mainly focused on searching the answer to these research questions.

1. What traditional skills of these Bishowkarmas of Hemja are still in existence?

2. What is the main basis of livelihood among Bishowkarmas?

3. How much do they earn from the traditional occupation?

4. What do Bishowkarmas feels about on their own traditional occupation?

5. What are the respondents' perceptions towards their occupational shift?

6. What do Bishowkarmas view the real causes for such shift?

7. Among the Bishowkarmas which new occupation is mostly preferred?

8. How much do they earn from the new occupation?

9. Are they really satisfied in the shift occupation?

10 . What do they expect from society and state?

In line with the above research questions, the general objective of this study is to find out the patterns of occupational shift among the Dalits (Bishowkarmas) in Hemja V.D.C. The specific objectives are :-

1. To study the changing patterns and occupational preferences among the Bishowkarmas. 
2. To assess the factors that fostered shift in their occupation.

3. To find the Dalits expectation from the society and the state.

Figure 1.1 : Conceptual Framework for Occupational Change among Bishowkarmas of Hemja.

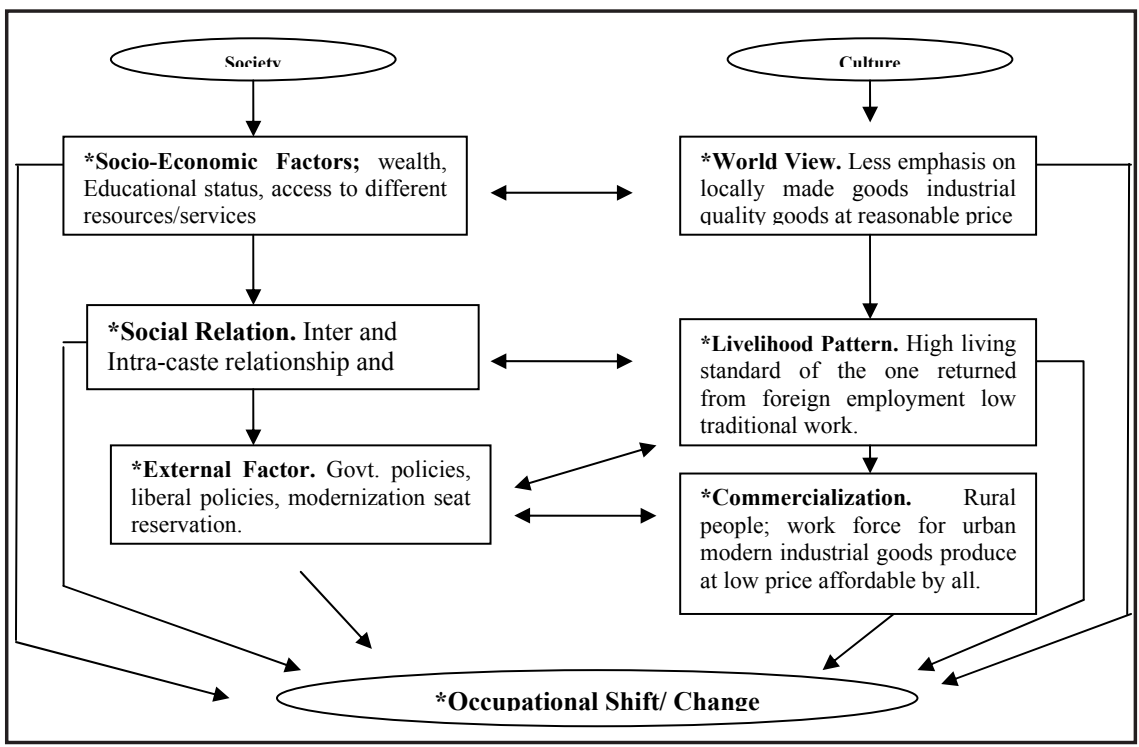

\section{DESCRIPTION OF THE STUDY SITE}

This study covers an area of ward no. 1, 6, and 9 of Hemja VDC (Figure 4.2), a city oriented VDC. It is situated to the north west of the zonal headquarter, Pokhara a sub-metropolis, in Kaski district of Gandaki zone. The east longitude and geographical location of the study is in between north latitude is $28^{\circ} 24^{\prime}-28^{\circ} 30^{\prime}$ north latitude and $83^{\circ} 58^{\prime}$ $84^{\circ} 00^{\prime}$ east longitude, the land topography varies from an altitude of 860 meters to 1415 meters above the sea level. The study site is plain which is known as Hemja Bensi. It has a fertile land formed by the rivers surrounding it to three sides. To its southeast it has Yamdi River and to its northeast it is border by Seti River. They meet at Yamdi to the bordered of Pokhara. It is bordered by Lamachaur and Simpani, the wards of Pokhara to its east, Dital, Dhampus, and Dhikurpokhari 
VDC.in the west, Puranchuar and Lahhachowk VDCs in the north and Sarangkot and Kaskikot VDCs in the south. The Pokhara-Baglung highway (70 Km long) runs through the VDC touching almost all the wards connecting it with the rest part of the country. It has created an easy access to come in contact with the urban people and work in the factories. At the same time, it also helps the people to increase economic and social development of the study area (VDC. Profile, 2003).

\section{RESEARCH METHODS}

Descriptive Research Design: Descriptive Research Design is used to describe the changing factor for the occupational shift. In this study the people's perception and the social adjustment of new changed of Bishowkarmas has been studied.

Census Study: This study tried to apply a more holistic approach. For that the universe of this study site of Bishowkarmas households build in ward no. 1, 6 and 9 of Hemja V.D.C., is taken as a whole. The universe of this study site had only 60 household. Due to the small population size, the researcher had conducted census study for his research.

Household Enumeration: In the first phase of the study, household enumeration was conducted. All the household in the universe were enlisted on the basis of house number given by Hemja V.D.C.

Pre-testing of Interview Schedule: In order to test schedule, a pretest (pilot survey) was carried out. For the purpose, the pilot survey was carried in the 'Sainik' a small rural town in Bhandardik Lekhnath municipality among the 10 households on $30^{\text {th }}$ September, and $1^{\text {st }}$ of October. The results of pre-test were tabulated and analyzed. This analysis helped to refine the questions in the schedule and to discover the new aspects about the changing pattern of occupation among the Bishowkarmas. Some important inferences and insights obtained from this procedure were incorporated into the schedule before printing its final version.

Interview Schedule: This technique had been the main basis of collection of primary data. To collect required data an interview schedule with both open and close ended questions were prepared 
and pre-tested. A careful attention was provided while constructing and structuring the schedule. The questions included in the interview schedule were framed in such a way that they could provide both qualitative and quantitative data. Importantly the questions in the interview schedule were of structured type.

Observation: Observation technique was adopted in various steps in order to study various aspects in the research site. Frequently observations on Bishowkarmas were made in different time period during field visit and field work. The observation adopted was both structured as well as unstructured, but mostly structured observation was done to get more qualitative data. During this their outgoing record were recorded.

Focused Group Discussion: For the focus group discussion, a checklist was prepared and finalized with the help of thesis supervisor, colleagues and with the cordial support from Mr. Amrit Kumar Bhandari teaching assistant of Sociology/Anthropology at P.N. Campus Pokhara. The issues of the group discussion were the causal factors for the occupational change among the Bishowkarmas and the objectives of this study. Two FGD sessions were help with the respondents and nonrespondent of the interview schedule. Both the sessions were attained by $8-10$ members.

Case Studies: Two separate case studies with the participants and their groups were also carried out to know the major aspects of the changing occupational pattern and its impacts on them. To get special insights on certain aspects and to collect more important qualitative data, this case study has also triangulated the collected qualitative data.

Validity and Reliability: The validity of the instrument was maintained by consulting with research supervisor, experts and concerned persons. Extra emphasis had been given to maintain the objectiveity of the data and avoid data error by comparing them with different data collected from different sources. Likewise, reliability of the data had been ensured by the careful planning of the questions in the interview schedule.

Method of Data Analysis and Presentation: All the collected data had been analyzed both qualitatively as well as quantitatively. Quantifiable raw data had been analyzed by using computer software 
SPSS. 11. for windows. While presenting the data, simple statistical tools like; frequencies and percentage had been used. Likewise, tabulation and graphical representation had also been made. The nonquantifiable qualitative data had been managed manually and analyzed descriptively. In order to present some quantitative data figures, charts, diagrams had been used. Some case studies reports were also included in this report to support the analysis and discussion. Similarly, suitable photographs taken during field visit were inserted for better illustration and reinforcement and the evaluation aspects of the report.

\section{MAJOR CHANGING PATTERN AND OCCUPATIONAL PREFERENCES}

Traditional occupation and involvement: Out of the total respondents from the field surveyed 75 percent of the respondents reported that iron related work was their traditional occupation. In this occupation they used to manufacture and repair agricultural tools. Similarly 11 percent of them reported gold related work, 5 percent each stated agricultural work and wood work respectively as their traditional occupation. It included working in the agricultural field as 'Hali and Bause' whereas 1.7 percent of the respondents reported that they did not know about their traditional occupation, since none of their known ancestors had followed any static occupation. On the basis of the given data, we can conclude that the traditional occupation of the Bishowkarmas of Hemja is iron related work or 'Blacksmith'. Majority of them reported so. In the case of involvement in the traditional occupation it was found too little. The least no. of respondents (21.6 percent) reported that their family member were involved in the caste based occupation. It is due to the gradual change in the socio-political scenario of the state and the advent of education had made these groups to realize their status in the society. Following the traditional occupation has ranked them low in the society. So the young generations are distracted from the traditional occupation. So they have started some new occupation.

Preference of new occupation and causes: the surveyed report exhibits the facts that the important fact discovered was that none of the young people are following their traditional work. They even lacked knowledge and skill towards their traditional occupation. These might be because of the lack of interest towards it, while on 
the other hand the field survey report showed that 60.2 percent of the respondents preferred new occupation for the higher earning of the income. For which they were forced to go abroad and to work there, when they were asked by the researcher, "Why had you chosen the foreign employment?" 11 percent of the respondents mark that they no job opportunities in the native homeland. Similarly, 15 percent of the respondents reported, that they could get an opportunity to see the foreign country. The miserable fact discovered by the researcher was that, the one that were involved in traditional work was due to lack of alternatives. Otherwise these people too might do so. Another fact was that the rate of mechanization was very high. That was replacing the traditionally manufactured goods, as well as other caste people were also found of adopting the similar occupation, that is also leading the disappearance of traditional occupation.

\section{CURRENT STATUS OF TRADITIONAL OCCUPATION}

1. Traditional Skills Getting Disappeared: The collected data from the field had illustrated that 30 percent of the respondents changed making agricultural tools and weapons. That is because of the easy and cheap availability of the tools from the agricultural industries, whereas the traditionally manufactured goods were comparatively higher in prices. So, the traditional worker to sustain in the market started producing the low quality goods. Similarly, 18.3 percent reported that, due to westernization the ancient skills were devalued. So they were compelled to manufacture the goods for the contemporary market. Due to which, wood work is completely on the way to lose its originality. Likewise 3.3 percent reported that the skill of making gold ornaments was getting disappeared; due to the fashionable demand of the market. The old ornaments like "Tilahari", "Bulaki", etc are getting disappear, whereas 48.3 percent remained silent, because they had already left the traditional occupation by one or two generation earlier.

\section{Cause for the Disappearance of the Traditional Occupation: No} one would like to be treated as inferior whatever may be their age, sex and occupation and other accomplishments in life. It is a universal fact of human nature that everybody wants to be respected and recognized. Not only that they would like to be treated as princes and kings and great 
personalities but also as simple humble human beings who are to be recognized and respected. Most of the respondents told the researcher that they had no ideas behind the disappearance of their traditional occupation. 18 percent of the respondents reported that, due to the lack of resources the caste base occupations were getting disappeared. The raw materials cost touched the sky. These groups were unable to buy it. Whereas 8.3 percent of them reported that, they could not deny the influence of the industrialization and mechanization. This is helping to produce goods in cheap price. They believed that it was the main factor behind the disappearance of the traditional occupation. Beside this 6.7 percent reported that the main causes behind the disappearance was due to low income generation as well as it was a source of social discrimination. They also reported that it was quite difficult to follow. Similarly, 5 percent of them reported that now-a-days other caste people were also reported to be involved in this occupation, they possessed greater means. So, it was getting disappeared from the original caste. Most importantly it was the caste base discrimination, which still existed in the society, that helped the youth to reluctant from their traditional occupation and moved in search of new occupation, that would provide them higher social status and respectable position in the society. Beside this fact Bishowkarmas were found of shifting the occupation for the better earning and higher saving.

\section{MANAGEMENT STRATEGY FRAMEWORK FOR THE PROMOTION OF TRADITIONAL OCCUPATION}

The field survey and use of other tools concern established caste based discrimination and industrialization as major problem that rendered them to shift to their caste based occupations. Basic policies for promotion of traditional occupational skills and technologies includes: Financial help from the government, end of untouchable practice, provision of reservation, and arrangement of markets for the traditional goods. To achieve this target, there exists a need of an integrated and holistic approach along with sharing of responsibilities and benefits among the study population.

The provision of reservation is not clear. It should not be only for economic upliftment but, also for social upliftment as well. 
The government's foremost concern is to make job guarantee to this group, to that the status of Bishowkarmas can be uplifted. They also report again that the government should not be in any confusion while defining the Dalits. It is straight-forward that Dalits are those who are religiously discarded, socially oppressed, economically exploited, politically suppressed and educationally deprived. So the movement of development should be from bottom for economic upliftment and from the top for abolishing untouchability against Dalits. The respondents stressed that; government should invest to develop the traditional skills of Bishowkarmas. The traditional skills should be modernized. There should be no government taxes for the industries and enterprises related to Bishowkarmas traditional skills. This will help to safe from being endangered.

The respondents report that, serious constraints for the Bishowkarma's empowerment are the prevailing caste base discrimination. That is reported by 12.1 percent. They told the researcher that they were discriminated by the high caste and indigenous nationalities in many areas of their social, economical and political life. They further reported that they didn't feel socially equal with these groups of people. 11.6 percent of the respondents said that up to today they had not been courage to protest discriminatory behaviours and they reluctantly accepted these as their fate.

\section{CONCLUSION}

The income presently earned by the respondents performing different occupation beside the traditional one is an undeniable significant component of the village economy. Majority of the household of the respondents in the study site could not satisfy their needs by adopting traditional occupation. So, they are compelled to choose the alternative occupation for the fulfillment of their needs. The respondents have no complete food security in the sense of access to the nutritious food and their living standard is also very low. Traditional occupation alone cannot meet the modern requirements. Traditional and ancient skills for the work are insufficient to meet the determined minimum level of food and clothing needs. Caste exploitation and discrimination is the main cause for the low earning from the traditional occupation. This 
has also remained a source of subordination to the Dalits. Beside this it urge the low earning. So the respondents cannot only rely on the caste based occupation. Adopting a new occupation has contributed to increase the access to other livelihood assets. In this respect, the respondents of the study site are also socialized to be familiar with the adoption of new occupation leaving the traditional one. Adoption of changing occupational patterns has been a survival strategy among the Bishowkarmas of the present Hemja VDC. The relationship of changing occupational patterns is also examined with reference to several aspects of opportunity structure like education, occupational prestige and size of family. It is observed that education has a direct bearing on gross and upward occupational mobility. The higher educational status is closely associated with greater gross and upward occupational mobility rate. Similarly, the level of educational attainment has a positive association with educational aspiration of the respondents for themselves as well as for their children. The occupational prestige grades have important bearing on the dissatisfaction with the present occupation. Lower the occupational prestige, the greater is the dissatisfaction to their traditional occupation. Similarly, the occupational prestige is an important explanatory variable in the preference of the occupational prestige of the respondents for themselves and to their children. Family size had positive association with gross and upward occupational mobility rate. Increasing wide gap between the people in the name of caste or caste based occupation is up to great extent responsible for the reluctant of traditional occupation. Though the goods have higher demand but in low price from the consumer. That is only possible when it is produced in massive rate like industries. So another factor behind the disappearance of traditional occupation is because of wide use of the modern industrial goods. The mechanization has replaced the traditional arts and skills. So it is clearly seen that some important policies for the modernization of Bishowkarmas skill and traditional occupation are vary essential. Increasing mass poverty can only be eliminated only when the society is free from 'Brahaminism', and provide equal access of opportunity to all. Beside these there must be the proper availability of raw materials and easy access of market for the produced goods. 


\section{REFERENCE CITED}

B. K., Amar. (2007). “The Process of Sanskritization: An Anthropological

Study Based on a Dalit Village of Lamachour VDC,

Kaski,". An Unpublished M.A. Dissertation. Pokhara:

TU, P N Campus.

Hemja VDC. (2003). Village Profile: Hemja. Kaski: Hemja Village Development Office, Hemja

Kisan, Yam B., (2005). The Nepali Dalit Social Moment. Lalitpur: Legal Right Protection Society Nepal, Kupondol, Lalitpur, Nepal.

Pandey, Madhusudhan, (2006). Nepalma Dalitko Esthiti, Kathmandu: Ratna Publication.

Sharma, Kedar. (2001). Positive Life. (Ed.). Kathmandu: Pamos South Asia Publication.

UNDP (2000). Human Development Report: 2000. New York: United Nations Development Programme. 